\title{
Enantioselective Sensing of Chiral Carboxylic Acids
}

\author{
Supporting Information
}

\author{
Xuefeng Mei and Christian Wolf* \\ Department of Chemistry, Georgetown University, Washington, DC 20057 \\ cw27@georgetown.edu
}

\section{General Procedures.}

All reactions were carried out under nitrogen. Commercially available reagents and solvents were used without further purification. 1,8-Dibromonaphthalene was prepared from 1,8-diaminonaphthalene as described in the literature. ${ }^{1}$ Flash chromatography was performed on silica gel (particle size $0.032-0.063 \mathrm{~mm}$ ). NMR spectra were obtained at $300 \mathrm{MHz}\left({ }^{1} \mathrm{H} \mathrm{NMR}\right)$ and $75 \mathrm{MHz}\left({ }^{13} \mathrm{C} \mathrm{NMR}\right)$ using $\mathrm{CDCl}_{3}$ as the solvent. Chemical shifts are reported in ppm relative to TMS. Elemental analysis data were collected using a Perkin Elmer $2400 \mathrm{CHN}$. Atmospheric pressure chemical ionization (APCI) mass spectra were collected on a YMC-Pack CN column $(4.6$ x $250 \mathrm{~mm})$ using an HP 1100 HPLC/MSD equipped with electrospray and atmospheric pressure chemical ionization MS detection and hexanes/EtOH (9:1) as the mobile phase.

\section{Synthetic Procedures.}

\section{3-(3,5-Dimethylphenyl)aniline, 3.}

To a solution of 3-bromoaniline, 2, (17.2 g, $0.10 \mathrm{~mol}), 3$,5-dimethylphenylboronic acid $(16.5 \mathrm{~g}, 0.11 \mathrm{~mol}), \mathrm{CsF}(50 \mathrm{~g}, 0.33 \mathrm{~mol}), \mathrm{Pd}_{2}(\mathrm{dba})_{3}(0.92 \mathrm{~g}, 5 \mathrm{mmol})$ in $50 \mathrm{~mL}$ anhydrous THF was added a solution of $\mathrm{P}(t-\mathrm{Bu})_{3}(0.49 \mathrm{~g}, 2.4 \mathrm{mmol})$ in $3 \mathrm{~mL}$ of THF. The exothermal reaction was cooled using a water bath. The solution mixture was stirred at room temperature for 2 hours and concentrated in vacuo. The residue was dissolved in methylene chloride and washed with water. The combined organic layers were dried over $\mathrm{MgSO}_{4}$ and solvents were evaporated. Purification of the orange residue by flash chromatography (100:10:1 hexanes:ethyl acetate:triethylamine) afforded $\mathbf{3}$ (20.0 g, 99 \%) as a brown oil.

${ }^{1} \mathrm{H}-\mathrm{NMR} \delta=2.30(\mathrm{~s}, 6 \mathrm{H}), 3.53(\mathrm{bs}, 2 \mathrm{H}), 6.50(\mathrm{dd}, J=2.5 \mathrm{~Hz}, 7.1 \mathrm{~Hz}, 1 \mathrm{H}), 6.77(\mathrm{~d}, J=$ $1.6 \mathrm{~Hz}, 2.2 \mathrm{~Hz}, 1 \mathrm{H}), 6.91(\mathrm{~s}, 1 \mathrm{H}), 6.94(\mathrm{dd}, J=1.2 \mathrm{~Hz}, 2.5 \mathrm{~Hz}, 1 \mathrm{H}), 7.10-7.15$ (m, 3H). ${ }^{13} \mathrm{C}-\mathrm{NMR} \delta=22.2,115.4,119.3,125.7,129.5,130.2,138.7,141.8,143.3,145.7$. Anal. calcd. for $\mathrm{C}_{14} \mathrm{H}_{15} \mathrm{~N}$ : C, 85.28; H, 7.61; N, 7.11. Found: C, 85.61; H, 8.01; N, 7.00.

\section{N-3-(3,5-Dimethylphenyl)anthranilic acid, 4.}

A mixture of 3-(3,5-dimethylphenyl)aniline 3 (5.3 g, $27 \mathrm{mmol})$, 2-chlorobenzoic acid (4.2 $\mathrm{g}, 27 \mathrm{mmol}), \mathrm{K}_{2} \mathrm{CO}_{3}(4.1 \mathrm{~g}, 30 \mathrm{mmol}), \mathrm{Cu}$ powder $(0.05 \mathrm{~g})$, and $\mathrm{Cu}_{2} \mathrm{O}(0.05 \mathrm{~g})$, in $5 \mathrm{~mL}$ of 2-methoxyethanol was refluxed for 2 hours. The cooled reaction mixture was poured into $30 \mathrm{~mL}$ water. Charcoal was then added and the solution was filtrated through Celite. The crude product was obtained by acidification of the filtrate with diluted $\mathrm{HCl}$ at ambient temperature, and subsequent recrystallization from acetone/water (1:8). The crystals were dissolved in $100 \mathrm{~mL} 5 \%$ aqueous $\mathrm{Na}_{2} \mathrm{CO}_{3}$. The solution was filtered through Celite and the product was precipitated by acidification to afford acid 4 (8.1 g, 95 $\%$ ) as a light yellow powder. 
${ }^{1} \mathrm{H}-\mathrm{NMR} \delta=2.39(\mathrm{~s}, 6 \mathrm{H}), 4.43(\mathrm{~s}, 2 \mathrm{H}), 6.77(\mathrm{dd}, J=7.1 \mathrm{~Hz}, 7.6 \mathrm{~Hz}, 1 \mathrm{H}), 7.02(\mathrm{~s}, 1 \mathrm{H})$, 7.22-7.50 (m, 8H), $8.06(\mathrm{~d}, J=8.0 \mathrm{~Hz}, 1 \mathrm{H}) .{ }^{13} \mathrm{C}-\mathrm{NMR} \delta=21.7,113.7,114.4,115.9$, $117.5,121.9,122.1,123.1,125.2,128.7,129.3,129.8,133.9,135.3,138.5,140.9,143.0$, 149.1. Anal. calcd. for $\mathrm{C}_{21} \mathrm{H}_{19} \mathrm{NO}_{2}$ : C, 79.50; H, 5.99; N, 4.42. Found: C, 79.10; H, 6.23; $\mathrm{N}, 4.32$.

\section{9-Bromo-3-(3,5-dimethylphenyl)acridine, 5.}

Acid 4 (1.0 g, $3.15 \mathrm{mmol})$ was suspended in $11.0 \mathrm{~g}(38 \mathrm{mmol})$ of phosphorus oxybromide, and the mixture was heated to $120{ }^{\circ} \mathrm{C}$ for 2 hours. Excess phosphorus oxybromide was removed by distillation and the residual solution was poured into a 1:1 mixture of aqueous ammonium hydroxide: $\mathrm{CH}_{2} \mathrm{Cl}_{2}$. The $\mathrm{CH}_{2} \mathrm{Cl}_{2}$ solution was separated, dried, and dried in vacuo. Purification of the orange residue by flash chromatography (100:100:1 hexanes:methylene chloride:triethylamine) gave $5(0.5 \mathrm{~g}, 45 \%)$ as a yellow powder.

${ }^{1} \mathrm{H}-\mathrm{NMR} \delta=2.44(\mathrm{~s}, 6 \mathrm{H}), 7.09$ (s, 1H), 7.46 (s, 2H), 7.63 (ddd, $J=1.1 \mathrm{~Hz}, 6.6 \mathrm{~Hz}, 8.8$ $\mathrm{Hz}, 1 \mathrm{H}), 8.28(\mathrm{dd}, J=8.5 \mathrm{~Hz}, 6.9 \mathrm{~Hz}, 1 \mathrm{H}), 7.92(\mathrm{dd}, J=1.6 \mathrm{~Hz}, 9.1 \mathrm{~Hz}, 1 \mathrm{H}), 8.22(\mathrm{~d}, J=$ $8.8 \mathrm{~Hz}, 1 \mathrm{H}) 8.39-8.47(\mathrm{~m}, 3 \mathrm{H}) .{ }^{13} \mathrm{C}-\mathrm{NMR} \delta=22.0,125.3,125.5,126.0,126.7,127.0$, 127.2 , 127.5, 127.8, 129.9, 130.2, 130.4, 135.4, 138.6, 139.3, 142.8, 149.2, 149.2. Anal. calcd. for $\mathrm{C}_{21} \mathrm{H}_{16} \mathrm{NBr}$ : C, 69.61; H, 4.42; N, 3.87. Found: C, 70.03; H, 4.30; N, 3.40.

3-(3,5-Dimethylphenyl)-9-trimethylstannylacridine, 6.

A solution of 9-bromo-3-(3,5-dimethylphenyl)acridine, 5, $(0.6 \mathrm{~g}, 1.6 \mathrm{mmol})$ in $10 \mathrm{ml}$ anhydrous diethyl ether:THF $(1: 1)$ was cooled to $-78^{\circ} \mathrm{C}$. To the solution was added $1.6 \mathrm{M}$ $n$-BuLi in hexanes $(2.4 \mathrm{mmol}, 1.5 \mathrm{~mL})$ dropwise over a period of $15 \mathrm{~min}$ and then a 1.0 $\mathrm{M}$ solution of $\mathrm{Me}_{3} \mathrm{SnCl}$ in hexanes $(3 \mathrm{~mL}, 3 \mathrm{mmol})$. The reaction mixture was allowed to warm to room temperature, stirred for 18 hours and concentrated in vacuo. Purification of the orange residue by flash chromatography (100:30:1 hexanes:ethyl acetate:triethylamine) afforded $6(0.65 \mathrm{~g}, 91 \%)$ as a yellow solid. GC-MS revealed contamination of the product with 5-10\% 3-(3,5-dimethylphenyl)acridine that could not be separated by chromatography. The stannane was therefore employed in the Stille cross-coupling with 1,8-dibromonaphthalene without further purification.

${ }^{1} \mathrm{H}-\mathrm{NMR} \delta=0.70(\mathrm{~s}, 9 \mathrm{H}), 2.44(\mathrm{~s}, 6 \mathrm{H}), 7.08-7.10(\mathrm{~m}, 1 \mathrm{H}), 7.49-7.56(\mathrm{~m}, 3 \mathrm{H}), 7.76$ (ddd, $J=1.4 \mathrm{~Hz}, 6.6 \mathrm{~Hz}, 8.8 \mathrm{~Hz}, 1 \mathrm{H}), 7.88(\mathrm{dd}, J=1.9 \mathrm{~Hz}, 9.1 \mathrm{~Hz}, 1 \mathrm{H}), 8.13(\mathrm{~d}, J=8.5 \mathrm{~Hz}$, $1 \mathrm{H}), 8.22(\mathrm{~d}, J=9.1 \mathrm{~Hz}, 1 \mathrm{H}), 8.27(\mathrm{~d}, J=8.5 \mathrm{~Hz}, 1 \mathrm{H}), 8.49(\mathrm{~m}, 1 \mathrm{H}) .{ }^{13} \mathrm{C}-\mathrm{NMR} \delta=-4.2$, $21.8,125.3,125.4,125.5,127.7,129.6,129.8,130.1,130.4,130.8,132.8,133.5,138.4$, $139.8,142.0,148.2,148.2,156.4$.

\section{1,8-Bis(3,3'-(3,5-dimethylphenyl)-9,9'-diacridyl)naphthalene, 1.}

A mixture of 1,8-dibromonaphthalene $(143 \quad \mathrm{mg}, \quad 0.50 \mathrm{mmol})$, tetrakis(triphenylphosphine)palladium $(0)(0.11 \mathrm{~g}, 0.10 \mathrm{mmol}, 30 \mathrm{~mol} \%)$, and $\mathrm{CuO}(80$ $\mathrm{mg}, 1 \mathrm{mmol})$ in $5 \mathrm{~mL}$ DMF was stirred at $140^{\circ} \mathrm{C}$. After $5 \mathrm{~min}$, a solution of 3-(3,5dimethylphenyl)-9-trimethylstannylacridine $6(0.90 \mathrm{~g}, 2.0 \mathrm{mmol})$ in $2 \mathrm{~mL}$ of DMF was added in one portion. After 16 hours, the reaction mixture was quenched with $10 \%$ aqueous ammonium hydroxide, extracted with diethyl ether, dried over $\mathrm{MgSO}_{4}$ and concentrated in vacuo. Purification of the orange residue by flash chromatography (100:5:1 hexanes:ethyl acetate:triethylamine) afforded 1 (100 $\mathrm{mg}, 30 \%)$ as a yellow solid. The diastereoisomers were separated into $60 \%$ of the anti-isomer and $40 \%$ of the syn-isomer. 
anti-Isomer: ${ }^{1} \mathrm{H}-\mathrm{NMR} \delta=2.45(\mathrm{~s}, 12 \mathrm{H}), 6.62-6.68(\mathrm{~m}, 2 \mathrm{H}), 6.83-6.86(\mathrm{~m}, 4 \mathrm{H}), 7.00-7.03$ (m, 2H), 7.07 (s, 2H), 7.31-7.39 (m, 8H), $7.67(\mathrm{~d}, J=9.1 \mathrm{~Hz}, 2 \mathrm{H}), 7.73-7.78(\mathrm{~m}, 2 \mathrm{H})$, $7.91(\mathrm{~s}, 2 \mathrm{H}) .8 .31(\mathrm{~d}, J=8.2 \mathrm{~Hz}, 2 \mathrm{H}) .{ }^{13} \mathrm{C}-\mathrm{NMR} \delta=22.3,124.8,125.4,125.5,125.6$, $125.9,126.2,126.3,126.6,127.0,129.3,129.8,130.1,130.5,131.2,134.2,134.6,135.5$, 139.0, 140.8, 141.9, 146.1, 147.5, 147.6. LC/APCI/MS: $\mathrm{m} / \mathrm{z}=691(\mathrm{M}+\mathrm{H})$. Anal. calcd. for anti- $\mathrm{C}_{52} \mathrm{H}_{38} \mathrm{~N}_{2}$ : C, 90.43; H, 5.55; N, 4.06. Found: C, 90.64; H, 5.30; N, 4.11.

syn-Isomer: ${ }^{1} \mathrm{H}-\mathrm{NMR} \delta=2.26(\mathrm{~s}, 12 \mathrm{H}), 6.65-6.70(\mathrm{~m}, 2 \mathrm{H}), 6.75-6.78(\mathrm{~m}, 2 \mathrm{H}), 6.85-6.88$ $(\mathrm{m}, 2 \mathrm{H}), 6.96-6.99(\mathrm{~m}, 4 \mathrm{H}), 7.12(\mathrm{~s}, 4 \mathrm{H}), 7.28-7.31(\mathrm{~m}, 2 \mathrm{H}), 7.36-7.42(\mathrm{~m}, 2 \mathrm{H}), 7.69-$ $7.75(\mathrm{~m}, 4 \mathrm{H}), 7.91(\mathrm{~d}, J=1.65 \mathrm{~Hz}, 2 \mathrm{H}), 8.27(\mathrm{dd}, J=1.1 \mathrm{~Hz}, 8.36 \mathrm{~Hz}, 2 \mathrm{H}) .{ }^{13} \mathrm{C}-\mathrm{NMR} \delta=$ $22.0,124.8,125.3,125.4,125.5,125.8,126.1,126.3,126.4,126.9,129.4,129.7,130.1$, 130.4, 131.1, 134.2, 134.7, 135.5, 138.8, 140.7, 142.1, 146.1, 147.4, 147.5. Anal. calcd. for syn- $\mathrm{C}_{52} \mathrm{H}_{38} \mathrm{~N}_{2}$ : C, 90.43; H, 5.55; N, 4.06. Found: C, 90.70; H, 5.40; N, 4.36.

\section{HPLC Enantioseparation and chiroptical measurements of 1.}

Chiral HPLC was carried out on an HP 1050 equipped with an autosampler and DAD detector using a $(R, R)$-WhelkO-1 column $(250 \mathrm{~mm} \times 4.6 \mathrm{~mm}, 5 \mu \mathrm{m})$ and hexanes/EtOH $(4: 1)$ as the mobile phase to separate the enantiomers of 1 . The levorotatory enantiomer was eluted first and the HPLC enantioselectivity factor, $\alpha$, was determined as 1.41. Preparative separations were performed by repetitive injections of $50 \mu \mathrm{L}$ of 1 dissolved in hexanes $/ \mathrm{EtOH} / \mathrm{CH}_{2} \mathrm{Cl}_{2}$ (50:50:1) at a concentration of approximately $10 \mathrm{mg} / \mathrm{mL}$. For analytical separations, $10 \mu \mathrm{L}$ of solutions containing 1 dissolved in the same diluent at a concentration of $1 \mathrm{mg} / \mathrm{mL}$ were injected.

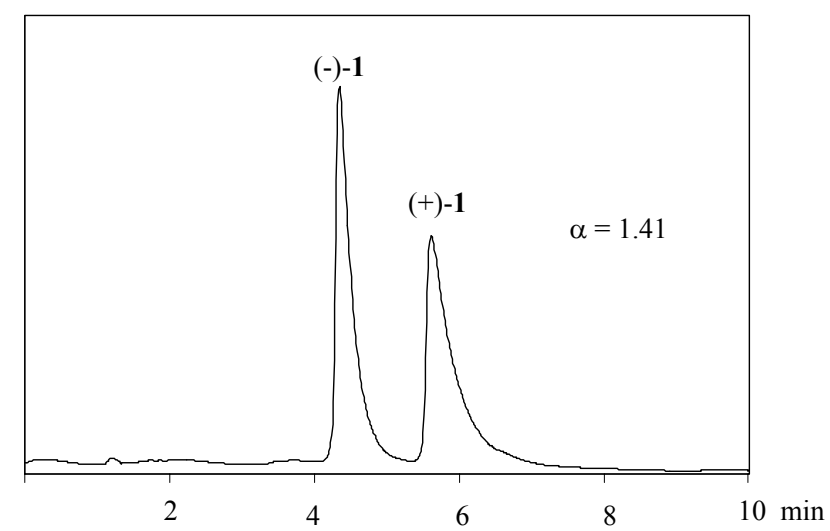

Figure 1. Enantioseparation of 1 on $(R, R)$-WhelkO-1. Diluent: hexanes/EtOH: $\mathrm{CH}_{2} \mathrm{Cl}_{2}=$ 50:50:1; mobile phase: hexanes/EtOH $=4: 1$; flow rate $=1 \mathrm{~mL} / \mathrm{min} ; 25^{\circ} \mathrm{C}$; UV detection: $254 \mathrm{~nm}$; injection volume: $10 \mu \mathrm{l}$; sample concentration: $1 \mathrm{mg} / \mathrm{mL}$.

Semi-preparative HPLC enantioseparation on $(R, R)$-WhelkO-1 allowed determination of the specific rotation by polarimetry as $[\mathrm{a}]_{589}^{25}=-392\left(1^{\text {st }}\right.$ eluted enantiomer, $\mathrm{c}=28$ $\mathrm{mg} / 100 \mathrm{ml} \mathrm{CH}_{2} \mathrm{Cl}_{2}$ ) and +371 (2nd eluted enantiomer, $\mathrm{c}=22 \mathrm{mg} / 100 \mathrm{ml} \mathrm{CH}_{2} \mathrm{Cl}_{2}$ ). Specific rotations were determined on a Rudolph Instruments Digipol 781 polarimeter. Circular dichroism spectra of the enantiomers of 1 were obtained at $5.0 \times 10^{-5} \mathrm{M}$ in acetonitrile on a JASCO J-710 circular dichroism chiroptical spectrometer. The CD spectra of the enantiomers of 1 are shown in Figure 2. 


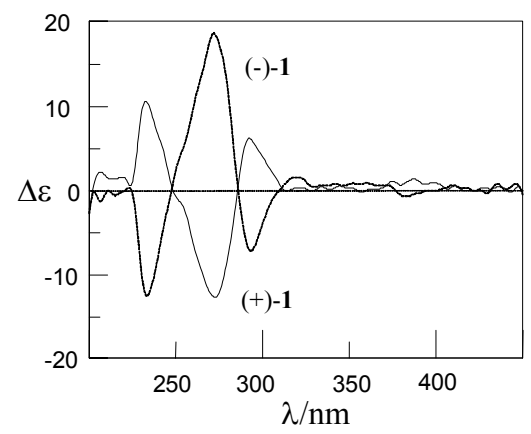

Figure 2. $C D$ spectrum of the enantiomers of $1\left(c=5 \times 10^{-5} \mathrm{M}\right)$ in acetonitrile.

\section{Fluorescence Spectroscopy}

Fluorescence experiments were conducted using a Fluoromax-2 from Instruments S.A. Inc. All emission spectra were collected under nitrogen using a $2.610^{-6} \mathrm{M}$ solution of $(+)-1$ in carefully degassed acetonitrile under inert atmosphere. Excitation wavelength was $360 \mathrm{~nm}$ and emission wavelength was $550 \mathrm{~nm}$. The quantum yield of 1 was determined as 0.17 following literature procedures. ${ }^{2}$ Diacridylnaphthalene 1 was excited at $360 \mathrm{~nm}$ and relative integrated intensities of the emission spectra were compared to anthracene in benzene. The fluorescence lifetime of anti-1 in acetonitrile was determined as $1.56 \mathrm{~ns}$. Frequency domain data were obtained with a $10 \mathrm{GHz}$ frequency domain fluorometer. ${ }^{3}$ The modulated excitation was provided by the harmonic content of a LASER pulse train with a repetition rate of $3.81326 \mathrm{MHz}$ and a pulse width of 7 ps from a synchronously pumped and cavity dumped pyridine 1 dye LASER. The dye LASER was pumped with a mode-locked Ar ion LASER (coherent). The dye LASER output was frequency doubled to $350 \mathrm{~nm}$ for excitation of $\mathbf{1}$. The emitted fluorescence was observed through a glass long wave pass filter $\left(\lambda_{\text {obs }}>520 \mathrm{~nm}\right)$. The fluorescence intensity decay data were fitted to the multi-exponential model $I(t)=\Sigma \alpha_{i} \exp \left(-t / \tau_{i}\right)$ where $\tau_{i}$ are the individual decay times and $\alpha_{i}$ are the associated preexponential factors. The parameters were recovered by non-linear least squares using the theory and software described elsewhere. $^{4}$

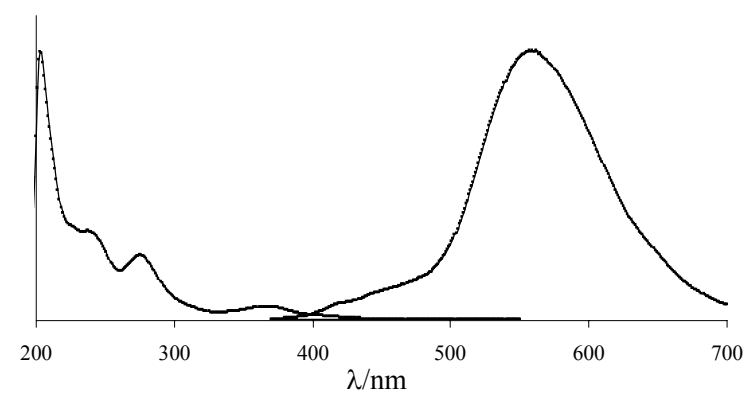

Figure 3. UV Absorption and fluorescence spectrum of $1\left(2.610^{-6} \mathrm{M}\right)$ in acetonitrile. Excitation wavelength was $360 \mathrm{~nm}$. The absorption and emission spectra have been normalized. 


\section{Stern-Volmer plots and Benesi-Hildebrand equations}
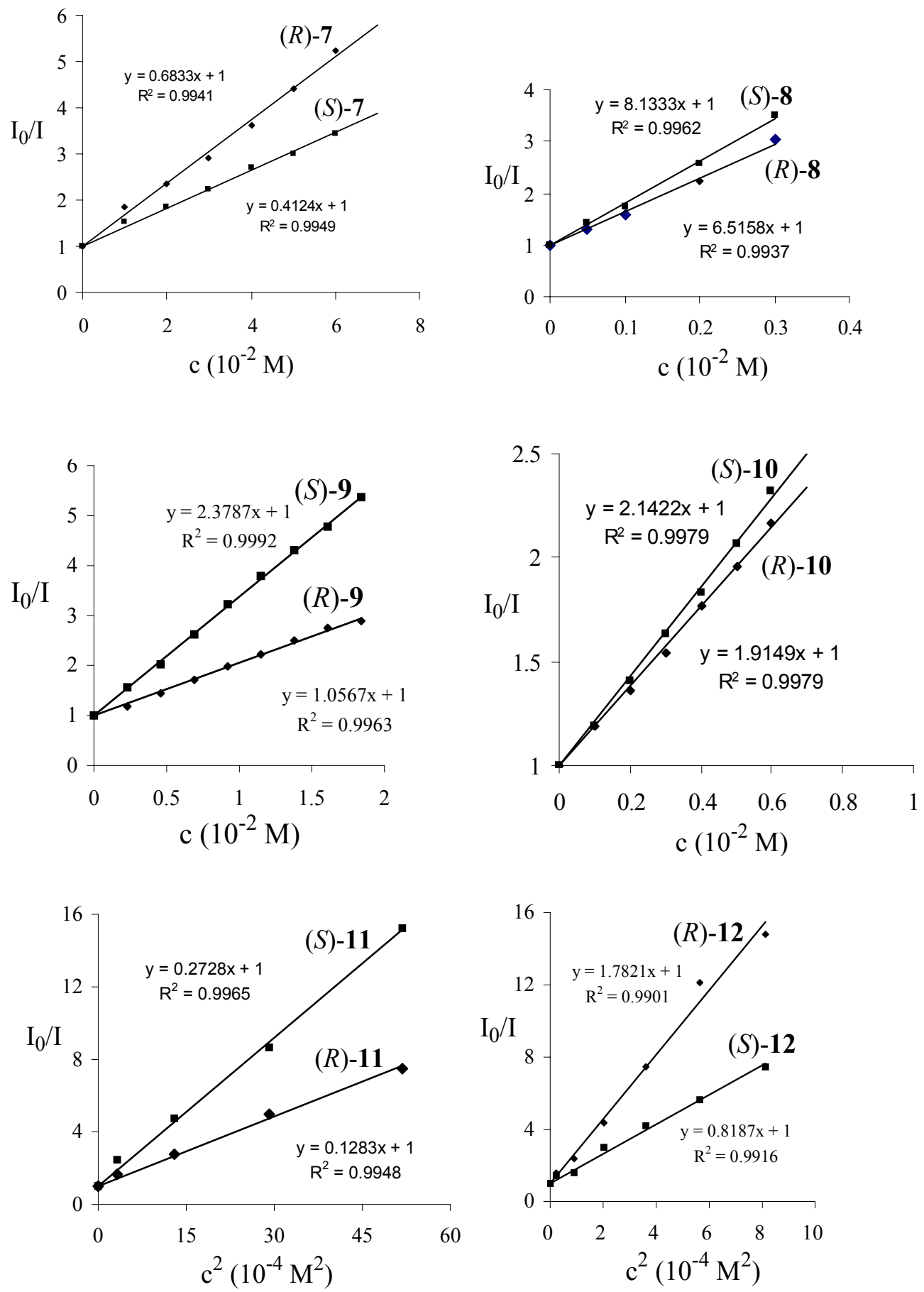

Figure 4. Linear Stern-Volmer plots for the enantioselective fluorescence quenching of $(+)-\mathbf{1}$ in the presence of carboxylic acids 7 to 12. The concentration of $(+)-\mathbf{1}$ in acetonitrile was $2.6 \times 10^{-6} \mathrm{M}$. Excitation (emission) wavelength: $360 \mathrm{~nm}(550 \mathrm{~nm})$. 

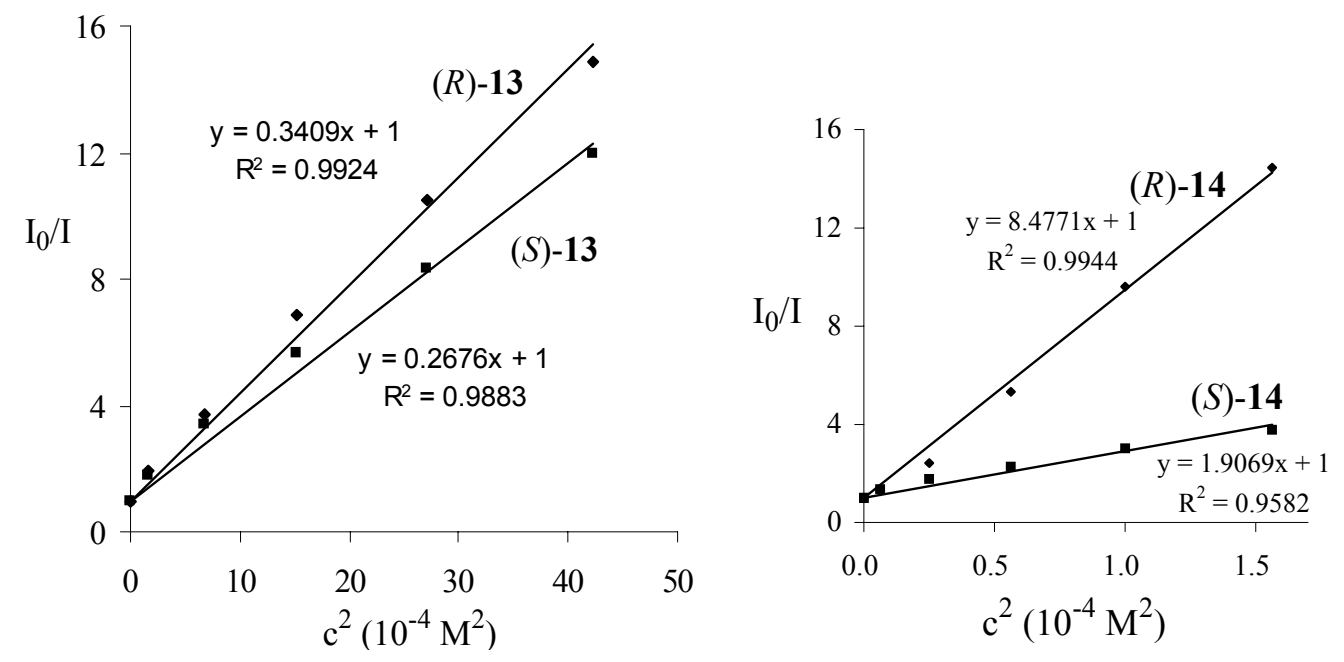

Figure 4 (contd.). Linear Stern-Volmer plots for the enantioselective fluorescence quenching of $(+)-\mathbf{1}$ in the presence of carboxylic acids $\mathbf{1 3}$ and 14. The concentration of $(+)-1$ in acetonitrile was $2.6 \times 10^{-6} \mathrm{M}$. Excitation (emission) wavelength: $360 \mathrm{~nm}$ (550 $\mathrm{nm})$.

Benesi-Hildebrand equations for 1:1 (a) and 1:2 (b) complexes:

$$
\begin{aligned}
& \frac{I_{0}}{I-I_{0}}=\frac{b}{a-b}\left\{\frac{1}{K[\mathrm{M}]}+1\right\} \\
& \frac{I_{0}}{I-I_{0}}=\frac{b}{a-b}\left\{\frac{1}{K[\mathrm{M}]^{2}}+1\right\}
\end{aligned}
$$

where $I_{0}$ is the inherent fluorescence intensity of $(+)-\mathbf{1}, I$ is the fluorescence intensity in the presence of an analyte, $[\mathrm{M}]$ is the analyte concentration, and $K$ is the association constant, $a$ and $b$ are constants. 


\section{Actual determination of the enantiopurity of 14 .}

In order to evaluate the accuracy and reproducibility of our sensing method we prepared nine samples with $\mathbf{1 4}$ in different enantiopurity and determined the enantiomeric composition based on the fluorescence quenching of $\mathbf{1}$. Three sample sets containing 15 , 55 , and $95 \%$ of $\mathbf{1 4}$ in acetonitrile were prepared and the fluorescence response of 1 in the presence of the analyte mixture was measured to calculate the enantiomeric composition using a calibration curve, Figure 5.

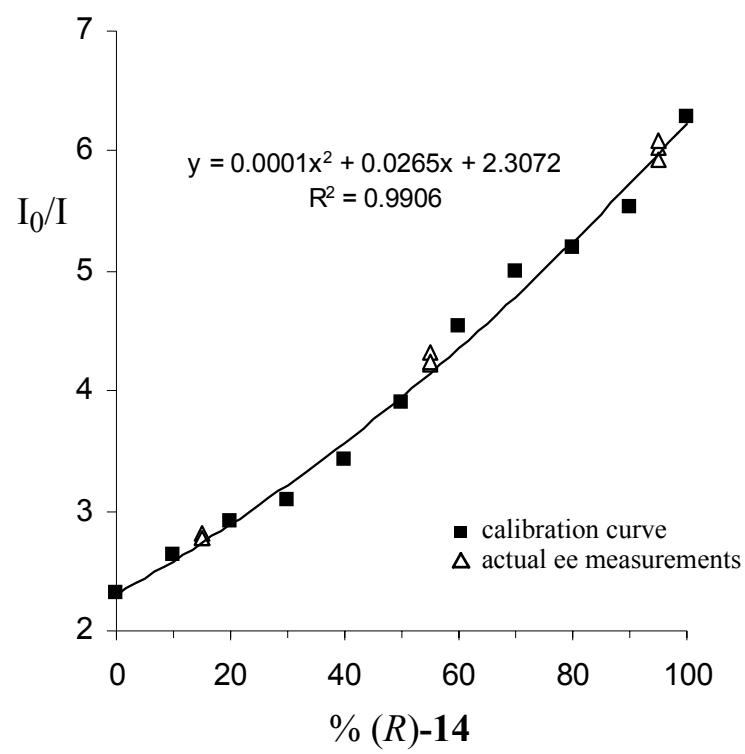

Figure 5. Calibration and actual enantiopurity measurement of nine samples containing 15,55 , and $95 \%$ of $(R)-14$. The concentration of the sensor was $4.4 \times 10^{-6} \mathrm{M}$ and the total concentration of $\mathbf{1 4}(R+S)$ was $1.25 \times 10^{-2} \mathrm{M}$ in acetonitrile. Excitation (emission) wavelength: $360 \mathrm{~nm}(550 \mathrm{~nm})$.

Table 1. Fluorescence quenching of $\mathbf{1}$ in the presence of $\mathbf{1 4}$ measured for calibration.

\begin{tabular}{ccc}
\hline$\%(R)$ & $\mathrm{I}$ & $\mathrm{I}_{0} / \mathrm{I}$ \\
\hline 0 & 70354 & 2.324019 \\
10 & 61948 & 2.639375 \\
20 & 56011 & 2.919141 \\
30 & 52849 & 3.093796 \\
40 & 47734 & 3.425315 \\
50 & 41878 & 3.904293 \\
60 & 35989 & 4.543166 \\
70 & 32725 & 4.996303 \\
80 & 31520 & 5.18731 \\
90 & 29509 & 5.540818 \\
100 & 25983 & 6.29273 \\
\hline
\end{tabular}

$\mathrm{I}_{0}$ was 163504. 
Table 2. Determination of the actual enantiopurity of nine samples of $\mathbf{1 4}$ by enantioselective fluorosensing using the calibration curve.

\begin{tabular}{ccccc}
\hline$\%(R)$ & $\mathrm{I}$ & $\mathrm{I}_{0} / \mathrm{I}$ & calculated $\%(R)$ & averaged $\%(R)$ \\
\hline 15 & 58888 & 2.776525 & 16 & \\
15 & 58298 & 2.804625 & 17 & 16 \\
15 & 59067 & 2.768111 & 16 & \\
\hline 55 & 38636 & 4.231908 & 57 & 58 \\
55 & 37780 & 4.327792 & 59 & \\
55 & 38547 & 4.241679 & 57 & 96 \\
\hline 95 & 27117 & 6.029576 & 96 & \\
95 & 26827 & 6.094755 & 97 & \\
95 & 27536 & 5.937827 & 94 & \\
\hline
\end{tabular}

The averaged enantiopurity of $(R)-\mathbf{1 4}$ calculated for each set of three samples were 16, 58 , and $96 \%$, Table 2 . The results are within $+/-3 \%$ of the actual enantiopurity of the samples of $\mathbf{1 4}$ and the data shown in Table 2 demonstrate the high reproducibility and accuracy of this method. 


\section{Crystallography}

Single crystal X-ray diffractions of 1 were performed at $-100{ }^{\circ} \mathrm{C}$ using a Siemens platform diffractometer with graphite monochromated Mo-K $\alpha$ radiation $(\lambda=0.71073 \AA)$. The structures were solved by direct methods and refined with full-matrix least-squares analysis using SHELX-97-2 software. Non-hydrogen atoms were refined with anisotropic displacement parameters and all hydrogen atoms were placed in calculated positions and refined with a riding model. Data were corrected for the affects of absorption using SADABS. Crystal data, collection parameters, refinement details, and key molecular parameters are shown in Table 1.

Table 3. Crystal data and structure refinement for 1.

\begin{tabular}{|c|c|c|}
\hline Empirical formula & \multicolumn{2}{|l|}{$\mathrm{C}_{52} \mathrm{H}_{38} \mathrm{~N}_{2}$} \\
\hline Formula weight & \multicolumn{2}{|l|}{690.84} \\
\hline Temperature & \multicolumn{2}{|l|}{$173(2) \mathrm{K}$} \\
\hline Wavelength & \multicolumn{2}{|l|}{$0.71073 \AA$} \\
\hline Crystal system & \multicolumn{2}{|l|}{ Monoclinic } \\
\hline Space group & \multicolumn{2}{|l|}{$\mathrm{C} 2 / \mathrm{c}$} \\
\hline Unit cell dimensions & $\begin{array}{l}\mathrm{a}=16.1895(13) \AA \\
\mathrm{b}=10.3998(9) \AA \\
\mathrm{c}=21.2941(18) \AA\end{array}$ & $\begin{array}{l}\alpha=90^{\circ} . \\
\beta=92.680(2)^{\circ} . \\
\gamma=90^{\circ} .\end{array}$ \\
\hline Volume & \multicolumn{2}{|l|}{$3581.3(5) \AA^{3}$} \\
\hline $\mathrm{Z}$ & \multicolumn{2}{|l|}{4} \\
\hline Density (calculated) & \multicolumn{2}{|l|}{$1.281 \mathrm{mg} / \mathrm{m}^{3}$} \\
\hline $\begin{array}{l}\text { Absorption coefficient } \\
\mathrm{F}(000)\end{array}$ & \multicolumn{2}{|l|}{$0.074 \mathrm{~mm}^{-1}$} \\
\hline Crystal size & \multicolumn{2}{|c|}{$0.30 \times 0.20 \times 0.10 \mathrm{~mm}^{3}$} \\
\hline Theta range for data collection & \multicolumn{2}{|c|}{1.91 to $24.99^{\circ}$} \\
\hline Index ranges & \multicolumn{2}{|c|}{$-19<=\mathrm{h}<=19,-12<=\mathrm{k}<=12,-25<=\mathrm{l}<=25$} \\
\hline Reflections collected & \multicolumn{2}{|c|}{13111} \\
\hline Independent reflections & \multicolumn{2}{|c|}{$3166[\mathrm{R}(\mathrm{int})=0.0375]$} \\
\hline Completeness to theta $=24.99^{\circ}$ & \multicolumn{2}{|c|}{$100.0 \%$} \\
\hline Absorption correction & \multicolumn{2}{|l|}{ Multiscan } \\
\hline Max. and min. transmission & \multicolumn{2}{|l|}{0.9927 and 0.9782} \\
\hline Refinement method & \multirow{2}{*}{\multicolumn{2}{|c|}{$\begin{array}{l}\text { Full-matrix least-squares on } \mathrm{F}^{2} \\
3166 / 0 / 247\end{array}$}} \\
\hline Data / restraints / parameters & & \\
\hline Goodness-of-fit on $\mathrm{F}^{2}$ & \multicolumn{2}{|c|}{1.087} \\
\hline Final $R$ indices $[\mathrm{I}>2 \operatorname{sigma}(\mathrm{I})]$ & \multicolumn{2}{|c|}{$\mathrm{R} 1=0.0485, \mathrm{wR} 2=0.1122$} \\
\hline $\mathrm{R}$ indices (all data) & \multicolumn{2}{|c|}{$\mathrm{R} 1=0.0697, \mathrm{wR} 2=0.1190$} \\
\hline Largest diff. peak and hole & \multicolumn{2}{|c|}{0.182 and -0.147 e. $\AA^{-3}$} \\
\hline
\end{tabular}

(1) Seyferth, D.; Vick, S. C. J. Organomet. Chem. 1977, 141, 178-187.

(2) Jones II, G.; Jackson, W. R.; Choi, C.-Y. J. Phys. Chem. 1985, 89, 294-300. 
(3) Laczko, G.; Gryczynski, I.; Gryczynski, Z.; Wiczk, W.; Malak, H.; Lakowicz, J. R. Rev. Sci. Instrum. 1990, 61, 2331-2337.

(4) Lakowicz, J. R.; Laczko, G.; Cherek, H.; Gratton, E.; Linkeman, H. Biophys. J. 1984, 46, 463-477. 